\title{
INTERNATIONAL REGULATORY CHANGES IN FINANCIAL SYSTEMS AS A FACTOR OF STABILITY
}

\author{
Dimitar Anevski ${ }^{1 *}$, Elena Temelkovska-Anevska ${ }^{2}$ \\ ${ }^{1}$ Komercijalna Banka AD Skopje, Branch Office Bitola \\ 18 Nikola Tesla Street, Bitola, R. Macedonia \\ ${ }^{2}$ Faculty of Law, University St. Clement of Ohrid \\ Partizanska bb Street, Bitola, R. Macedonia
}

\begin{abstract}
:
The necessity of regulating certain legal and finance systems derives from the possibility that they may have a major impact on essential processes in countries. Therefore, depending on the market conditions and integration intentions of specific political or financial groups, the countries are forced to implement new regulations. Such regulations are different everywhere in the world; there are hundreds of laws and legal acts arising from national and local governments, which cover various aspects of the economy. The paper examines the international capital agreements and legal acts responsible for the stability of the finance sector and its members, which lead to overall stability of a society. Analyzing the contemporary literature reveals the countries which have successfully managed to implement the high-demand criteria.
\end{abstract}

\section{Key words:}

regulation,

Basel standards, stability.

\section{INTRODUCTION}

Regulation of finance systems and supervision of its members has been the matter of interest and debate in recent times, largely because of the political and financial turmoil. The challenge for regulators worldwide, according to recent experiences obtained during the financial crisis, continues to be the design of an appropriate "safety net", which ensures the reliability of the finance system (Dorota, 2013, pp. 1-10). Therefore, besides the imperative of simply harmonizing regulations, it is particularly important that the regulatory framework is the same for all institutions in a single system. In this manner, the impact of legislation in terms of market competitiveness of banks is the same for all banks within a banking system (Poposka et al., 2013, p. 136).

Banks are one of the oldest financial institutions and subject to regulations since their foundation. The regulations aim to maintain a secure and stable banking system while protecting the interests of depositors and other creditors who have invested their own funds in the banks. 
They are intended to encourage competition, to create an efficient payment system, to protect the consumers and other financial institutions etc. These regulations also contribute to a more efficient allocation of capital, constant source of loans, supporting the clients and companies to balance their investment to the consumption (Ingves, 2015, p. 65). At the present time, there are multiple reasons for the regulation of the banking system. It is proven that countries that had the highest scores in terms of regulation quality were the countries least resistant to the global recession (Forbes et al., 2013, pp. 1-8). Certainly, the most important reason is the pressure that comes from the pace imposed by the globalization process through advances in communication technology, erasing borders between countries and so on. The globalization creates opportunities for carrying out operations abroad, without the need to physically build offices. The banks seized opportunities to expand their operations abroad, thus causing concern to government authorities by what means to harmonize and align national banking regulations among states.

\section{THE FIRST CAPITAL ACCORD - BASEL I}

The need for the regulation of the finance systems internationally is not new, although the reasons are similar. The main reason is to assure stability of the systems and to facilitate transfers of money and capital across national economies. In the period from 1965 to 1981, eight bank bankruptcies were reported in the United States, which was one of the reasons that the leaders of the central banks and supervisory authorities from 10 countries met in Basel, Switzerland, to prevent the recurrence risk (Fadi, 2017). In terms of stability, historically speaking, the first Capital Accord or Basel I was completed in 1988 and implemented by Member States by the end of 1992 (Goodhart, 2011; Toniolo, 2005; Bank for International Settlements, 2016). The main benefit of this agreement was submitted capital focus to risk exposures of individual banks and higher capital ratio encouraged. From January 1993, banks active internationally were obliged to comply with the minimum ratio of risk assets or „risk asset ratio” (RAR) of $8 \%$. Later, in January 1998, some banks had to include market risks despite the credit risks in the calculation, maintaining a minimum of 8\% RAR. In 1999, the World Bank and the IMF began with the FSAP - Financial Sector Assessment Program, in order to systematically approach the status of the banking systems in the countries and to propose specific recommendations for reform (Barth et al., 2012, pp. 2-5). In this regard, the Bank for International Settlements - BIS, the International Monetary Fund - IMF and the World Bank worked on designing effective strategies to reform the financial sector, passing on recommendations to states and providing assistance for their implementation in order to achieve efficiency and stability of the financial system in these countries. International regulation of the banking system was entrusted to the newly established Basel Committee on Banking Supervision, a part of the Bank for International Settlements in Basel, Switzerland, which consists of representatives of central banks and bank regulators in developed economies. The Banking Supervision Committee of Basel includes central banks representatives and regulatory establishments of the following states: Belgium, Canada, France, Germany, Italy, Japan, Netherlands, Sweden, Switzerland, the United Kingdom, the United States and Luxembourg (Bank for International Settlements, 1988, p. 1).

\section{THE SECOND CAPITAL ACCORD - BASEL II: A REVISED FRAMEWORK}

Since the first agreement showed deficiencies in terms of its application based on the free will of the Member States, in terms of the methodology proposed standardized approach, market distortions, etc., the Basel Committee on Banking 
Supervision, in June 1999, proposed fundamental adjustments to the original agreement. According to them, the new framework for the assessment of capital adequacy included three "pillars" covering:

I Pillar - Outlines the least capital requirements, II Pillar - Defines the process for supervisory review, and

III Pillar - Manages the discipline of the financial market.

\section{Pillar}

The minimum criteria for capital requirements remains unchanged with the minimum rate of $8 \%$, which is calculated through several core risk components: the risk of credit, the risk of operations and the risk of the market efficiency (Bronack, 2009). Concerning the credit risk, the Committee permits banks to select one of two approaches for calculating their requirements for capital in accessing the risk (Bank for International Settlements, 2006, p. 33). Banks can choose the standardized method that uses external credit assessments or the internal ratings-based approach, which is centring mainly on a bank's supervisor approval, and allows banks to utilize their own evaluation schemes for credit risk. Concerning the operational risk, banks are stimulated to use different available approaches in developing complex evaluation schemes and practices. Its frame comprises the following practices for calculating operational risk: the basic indicator method, the standardized method and the advanced measurement method (Bank for International Settlements, 2006, p. 158). The first approach is forcing banks to retain capital for operational risk equivalent to preceding three year average of a fixed percentage of positive yearly gross revenue. For the second standardized method, the activities of banks are separated into multiple corporate lines: agency services, asset management, commercial banking, finance, payment clearing, retail banking and brokerage and trading. Under the third method, capital requirements equal the amount of risk measured by the bank's own measurement system for operational risk, using the quantitative and qualitative criteria. Regarding the last method, the market risk is the matter of mechanisms associated to interest rate, trading book equities, foreign exchange and commodities risk in the bank (Bank for International Settlements, 2006, p. 171).

\section{Pillar}

The regulators use more progressive tools regarding the first accord, which are used by the second pillar to manage the challenges of the first one. This pillar offers a frame for risks such as the risk of concentration, legal and liquidity risks, systemic and strategic risks. There are four fundamental principles of the supervisory review (Bank for International Settlements, 2006, pp. 205-220). The first principle is obliging banks to implement the method for evaluating their overall capital adequacy in relation to the risk profile, also creating a plan for retaining their capital positions. The second principle is obliging supervisors to review the banks evaluations and strategies, as well as to observe and ensure their compliance with the capital ratios stipulated by the regulatory bodies. The third principle expects banks to function above capital ratios set by the regulatory bodies as a minimum and obliges banks to retain capital in addition to the minimum. The fourth principle is obliging supervisors to pursue timely intervention to prevent capital from decreasing below the minimum levels, which are obligatory to support a bank's risk structures and should require prompt corrective act if capital levels are not preserved or returned.

\section{Pillar}

The aim of the third pillar, known as the market discipline, is to balance the capital requirements from the first pillar and the process of supervisory 
review from the second pillar. This pillar objective is promotion of firmness in the financial system, allowing proper functioning of market discipline. That requires from banks the public risk controlling activities, the method of risk valuation and the risk dispersion. Done accordingly, the participants in the market will gather adequate information of the bank's activities and its methods for risk control, gaining ability to differentiate banks who rationally cope with risks.

The agreement requires banks to increase their capital ratio when facing higher risks. This means that banks will have less money available for lending during the recession or crisis (Gordy \& Howells, 2004). Though lending to small firms using standardized or internal ratings-based approaches points to the need for lower capital requirements than for loans to large firms, Basel II agreement still implies that riskier loans have higher capital requirements. Depending on the risk level, the costs for small firms can be more expensive than for loans to large companies. Basel II increases administrative costs to create and maintain the loan portfolio due to sophisticated new rules (Balling et al., 2009, p. 12). Systems for automated decision-making, rating or scoring models used for companies, are needed to evaluate the information in more beneficial and resourceful way (Altman \& Sabato, 2005, pp. 1-25).

The implementation of Basel II regulations vary from country to country. The EU countries had completed implementation followed by Australia, Brazil, Canada, India, Japan, Korea, Mexico, Saudi Arabia, Singapore, South Africa and Turkey. The institutions in the United States are enforced to implement the innovative methods to assess credit and operational risk. The banks made major improvements in implementing a parallel submission of information on Basel I and Basel II capital indicators on a periodical basis (Bank for International Settlements, 2013).

\section{THE THIRD CAPITAL ACCORD - BASEL III}

The Basel III framework is released on December 2010 and it builds on previous frameworks and enhances them. Basel III is a wide-ranging set of improvement methods (Bank for International Settlements, 2017) created by the Committee to reinforce the banking sector regulation and supervision and its risk management. This accord sets greater levels for capital requirements thus introducing different universal liquidity frame. For example, the Minimum Common Equity Capital Ratio rises from 3.5\% in 2013 to $4.5 \%$ in 2019 (Bank for International Settlements, 2013). The Capital Conservation Buffer is implemented with $2.5 \%$ till 2019. The Minimum common equity plus capital conservation buffer rises from 3.5\% in 2013 to $7 \%$ in 2019. Tier 1 minimum capital buffer rises from $4.5 \%$ in 2013 to $6 \%$ in 2019 . The Minimum Total Capital plus conservation buffer rises from $8 \%$ in 2014 to $10 \%$ in 2019 . There is also a change in liquidity, introducing Liquidity Coverage Ratio - the minimum requirement of $100 \%$ in 2019.

These measures aim at improving the banking sector's ability to absorb shocks caused by economic stress and financial risk management, as well as at strengthening banking transparency.

\section{The timeline and implementation progress of Basel III}

The implementation of Basel III regulations is in progress. If you take, for example, the European Union as a leader in the implementation of Basel II regulations, then it can be stated that the EU lost the leading position in the implementation of Basel III regulation, due to the required harmonization of the European Parliament, the Council and the Commission. However, EU countries have successfully implemented the standards. Other countries that have implemented the standards are Australia, Brazil, Canada, China, India, Indonesia, Mexico, Japan, Saudi Arabia, 
Singapore, South Africa, Switzerland and Turkey (Bank for International Settlements, 2013).

The Committee is monitoring the implementations of Basel III standards, presenting them in the updated reports. The members should adapt the following standards (Bank for International Settlements, 2016):

- Capital: the participants decided to implement Basel III starting from January 1,2013 , focusing on temporary and phase-in activities, with the deadline on January 1, 2019.

- Leverage ratio: the implementation began with bank-level reporting to national supervisors until January 1, 2015.

- Liquidity Coverage Ratio began with the implementation on January 1, 2015. This ratio is in a temporary preparation phase before proceeding to full implementation on January 1, 2019.

- NSFR or Net Stable Funding Ratio is to become a permanent standard by January $1,2018$.

- G-SIB framework requirements started with implementation on January 1, 2016, with the time limit of January 1, 2019, etc.

The empirical analysis showed that regulation of the financial system, including the Basel III framework, is helping to ensure the stability of the financial system reducing the likelihood of financial crises, although costs may occur in the short term. The regulation eliminates the risks and most importantly, there are also benefits to the society as a whole. Thus, the regulation of the banking system and the Basel III framework is especially important in supporting strong and steady growth (Ingves, 2015, p. 71).

\section{BENEFITS OF REGULATION}

The implementation of the Basel standards, though it entails costs in the banking sector, brings important advantages. The main advantage is the increase of confidence in banks. A bank that has implemented these standards is considered highly liquid and solvent even in times of unexpected crises. Besides the customers, bank shareholders have major benefits of implementing the standards because they know that the reports were prepared pursuant to strict regulation, transparent and reliable, which makes the assessment of management success easier. The third group that benefits from these standards includes corporate customers and the overall economy. The financial institutions that comply with these standards are resistant to shocks. In times of crisis, they continue to supply the much needed credit funds to the economy.

Basel III standards are intended for strengthening the capital framework and introducing new liquidity standards in order to strengthen the short-term resilience of banks and potential liquidity problems and protect the long-term mismatch of assets and liabilities. Therefore, the introduction of two liquidity rates is envisioned: the coverage rate of liquidity which may not be less than $100 \%$ and the net stable funding sources, which should also be over 100\% (National Bank of Macedonia,2010,pp.9-11). These two rates are more complex and therefore the Basel Committee opted for a long period of gradual implementation of the new liquidity standards, due to the need to adjust to them. For that reason, banks will be directed toward finding stable funding sources (deposits and long-term assets). It should be expected that this demand will increase competition between banks in attracting stable sources of funds and it will affect financing costs, net interest margin and profitability.

\section{ANALYSIS OF THE REGULATION IMPLEMENTATION BY FINANCIAL INSTITUTIONS IN THE REPUBLIC OF MACEDONIA}

The regulation of the banking system is complex and it is essential for banks to implement 
it in order to ensure its stability. In that context, the level of capital ratio, which banks are obliged to maintain, must be no lower than $8 \%$. The governor of the National Bank of Macedonia may prescribe a higher rate of $8 \%$ for a particular bank or a group of banks, if necessary due to the nature, category and range of activities executed by the bank and the risks to which it is vulnerable as a consequence of those activities. In addition to the paper, a comparison table (Table 1) on the rate of capital adequacy for groups of banks is presented for the period from 2004 to 2015 (Parliament of the Republic of Macedonia, 2015, Official Gazette no. 67/07, 90/09, 67/10, 26/13, 15/15 and 153/15, Article 65). Based on the data from the table, it can be concluded that banks, in the period covered by the analysis, fulfil the minimum statutory rate of capital adequacy ratio of $8 \%$. It can be noticed that the group of small banks has a constant rate fall since 2007 when it reached its maximum of $66.9 \%$, versus only $18.7 \%$ in 2015 . Nevertheless, the group of small banks still has the highest rate of capital adequacy, followed by the group of medium-sized banks. The lowest rate of capital adequacy has the large size bank group with only $14.9 \%$. In 2010, only one bank in this index was close to the total minimum of $8.5 \%$, with only $8.6 \%$. Taking into account the so far elaborated rate of capital adequacy, it can be confirmed that banks have successfully fulfilled this standard.

Nevertheless, the National Bank of the Republic of Macedonia expects uncertainty in certain segments of the banking system. The uncertainty expected in the coming years is based on the analysis made by the central bank (National Bank of Macedonia, 2015), processed from financial institution filled questionnaires. The risks that can distress the operation of banks are clustered into several groups. The first group comprises the risks of the macroeconomic environment, the second group the financial market risks, the third the risks in the banking segment, the fourth group involves strategic individual or group risks, and the last, fifth group contains the risks of regulation changes. Banks consider the risks rising from the macroeconomic environment to be the highest, followed by the banking segment risks and the regulation changes risks. Concerning the last regulatory risks, banks anticipate greater adjustment in the level of significance and influence of these risks on the processes. The expectations are founded on the subsequent potential risk elements, like the deficiency of transparency and participation of banks in the improvement of regulations that have impact on their operation, short time parameters for implementation of the different regulation, and non-compliance of regulations by separate national establishments. However, given the established goal to maintain the banking and financial system solid, the activities for consolidation of banking supervision will continue.

\section{CONCLUSIONS}

The financial crisis has shown that bank systems face major problems in terms of liquidity, solvency and high indebtedness. Therefore, it is clear that banking systems have to become resistant to all financial tremors in the future, whether they are expected or not. The international regulation is subject to constant change with the aim of providing a strong banking sector. Based on the elaborated, it can be concluded that banks in the Republic of Macedonia may keep up with modern trends, fulfil high regulatory requirements and satisfy the minimum criteria concerning the rate of capital adequacy. But not all financial institutions meet all of the criteria. Some of the banks are not facing problems while gradually implementing the Basel III standards. However, for some of them, it is necessary to carry out recapitalization, and a small part will probably face serious problems in implementation. This leads to the inevitable process of the banking sector consolidation, where a number of small banks are continuously going down. 


\section{REFERENCES}

Altman, I.E., \& Sabato, G. (2005). Effects of the New Capital Accord on Bank Capital Requirements for SME. Journal of Financial Services Research, 28(1), 1-25. DOI:10.1007/s10693-005-4355-5

Balling, M., Bernet, B., \& Gnan, E. (2009). Financing SMEs in Europe. Vienna: SUERF.

Bank for International Settlements. (2013, March). Status of adoption of Basel II regulations. Retrieved February 9, 2017, from http://www.bis.org/publ/ bcbs/b2prog_rep_table.pdf.

Bank for International Settlements. (2017, February). Basel III: international regulatory framework for banks. Retrieved February 9, 2017, from http:// www.bis.org/bcbs/basel3.htm.

Bank for International Settlements. (2013, March). Status of adoption of Basel III (capital) regulations. Retrieved February 9, 2017, from http://www.bis. org/publ/bcbs/b3prog_rep_table.pdf

Bank for International Settlements. (2013). Basel III phase-in arrangements. Retrieved March 25, 2017, from http://www.bis.org/bcbs/basel3/basel3_phase_ in_arrangements.pdf

Bank for International Settlements. (2016, December). History of the Basel Committee. Retrieved February 5, 2017, from http://www.bis.org/bcbs/history.htm.

Bank for International Settlements. (2016, December). Eleventh progress report on adoption of the Basel regulatory framework. Retrieved March 25, 2017, from http://www.bis.org/bcbs/publ/d388.pdf

Bank for International Settlements. (2006, December). International Convergence of Capital Measurement and Capital Standards: A Revised Framework Comprehensive Version. Retrieved February 10, 2017, from http://www.bis.org/publ/bcbs128.pdf.

Barth, J.R., Caprio, Jr.G., \& Levine, R. (2012). The Evolution and Impact of Bank Regulations. Policy Research Working Paper No. 6288, pp. 2-5. Retrieved February 11, 2017, from https://openknowledge.worldbank.org/handle/10986/12183

Basel Committee on Banking Supervision. (1988). International Convergence of Capital Measurement and Capital Standards. Basel: Bank for International Settlements. Retrieved February 11, 2017, from http://www.bis.org/publ/bcbs04a.pdf

Bronack, T. (2009, July). Basel II Overview, Data Center Assistance Group. Retrieved February 11,
2017, from http://www.dcag.com/images/Basel_II_ Overview.pdf.

Dorota, S. (2013). The Influence of Regulatory And Institutional Framework and Shareholder Structure Upon Risk of Financial Institutions in Central Europe. National Bank of Poland Working Paper No. 149, pp.1-10. DOI:10.2139/ssrn.2264066

Fadi, Z. (2017, February). How Basel 1 Affected Banks. Retrieved February 10, 2017, from http://www.investopedia.com/articles/07/baselcapitalaccord.asp

Forbes, W., O’Donohoe, S. \& Prokop, J. (2013). Financial Regulation and Nation State Crisis Management: Evidence from Germany, Ireland and the UK. Zentra Working Papers In Transnational Studies No. 18, pp.1-8. DOI:10.2139/ssrn.2264058

Goodhart, C. (2011). The Basel Committee on Banking Supervision: A history of the early years 1974-1997. Cambridge: Cambridge University Press.

Gordy, M.B., \& Howells, B. (2004). Procyclicality in Basel II: Can We Treat the Disease Without Killing the Patient? Retrieved February 8, 2017, from http:// www.bis.org/bcbs/events/rtf04gordy_howells.pdf.

Ingves, S. (2015). Supporting sustainable growth: The role of safe and stable banking systems. Financing the economy: New avenues for growth, Banque de France Financial Stability Review No. 19, pp. 65-72.

National Bank of Macedonia. (2010). Amendments to the Basel Capital Accord (Introduction of Basel 3) and preliminary estimates of their impact on the capital adequacy of banks in the country (pp. 9-11). Skopje: National Bank of Macedonia.

National Bank of Macedonia. (2015). Financial Stability Report for the Republic of Macedonia in 2014. Skopje: National Bank of the Republic of Macedonia.

National Bank of Macedonia. (2015). Strategic plan of the National Bank of Macedonia for the period 2016-2018. Skopje: National Bank of the Republic of Macedonia.

Parliament of Republic of Macedonia. (2015). Law on Banks. Skopje: Official Gazette No. 67/07, 90/09, 67/10, 26/13, 15/15 and 153/15, Article 65.

Poposka, K., Iloski, I., \& Todevski, D. (2013). Analysis of the profitability of banks, profitability Internal factors - case study. Skopje: Tabernakul.

Toniolo, G. (2005). Central Bank cooperation at the bank for international settlements, 1930-1973. Cambridge: Cambridge Univeristy Press. 


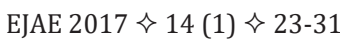

Anevski D., Temelkovska-Anevska E. \& International regulatory changes in financial systems as a factor of stability

\begin{tabular}{|c|c|c|c|c|c|c|c|c|c|c|c|}
\hline $\begin{array}{l}\text { Bank } \\
\text { Size }\end{array}$ & 2005 & 2006 & 2007 & 2008 & 2009 & 2010 & 2011 & 2012 & 2013 & 2014 & 2015 \\
\hline Large & $13.70 \%$ & $12.40 \%$ & $12.70 \%$ & $13.40 \%$ & $13.80 \%$ & $14.10 \%$ & $15.00 \%$ & $15.3 \%$ & $15.8 \%$ & $14.6 \%$ & $14.9 \%$ \\
\hline Middle & $27.60 \%$ & $23.80 \%$ & $20.90 \%$ & $16.70 \%$ & $17.40 \%$ & $17.00 \%$ & $17.20 \%$ & $22.2 \%$ & $18.8 \%$ & $18.0 \%$ & $16.3 \%$ \\
\hline Small & $42.40 \%$ & $49.80 \%$ & $66.80 \%$ & $61.90 \%$ & $48.10 \%$ & $54.70 \%$ & $38.60 \%$ & $18.8 \%$ & $17.6 \%$ & $18.7 \%$ & $18.7 \%$ \\
\hline $\begin{array}{l}\text { Banking } \\
\text { system }\end{array}$ & $21.30 \%$ & $18.30 \%$ & $17.00 \%$ & $16.20 \%$ & $16.40 \%$ & $16.10 \%$ & $16.80 \%$ & $17.1 \%$ & $16.8 \%$ & $15.7 \%$ & $15.5 \%$ \\
\hline
\end{tabular}

Table 1. - Capital adequacy by groups of banks in the Republic of Macedonia for the period 2005-2015.

Source: Summarized by the author based on Capital adequacy ratio data and indicators of the banking system of the Republic of Macedonia - Indicators of banks capital adequacy, the National Bank of Macedonia, as of December 31, 2015.

\section{PROMENE MEĐUNARODNE REGULATIVE FINANSIJSKIH SISTEMA KAO FAKTOR STABILNOSTI}

\section{Rezime:}

Neophodnost regulacije određenih pravnih i finansijskih sistema proizilazi iz mogućnosti da oni mogu imati veliki uticaj na osnovne procese u zemljama. Stoga, u zavisnosti od tržišnih uslova i namera integracije određenih političkih ili finansijskih grupa, zemlje su primorane da sprovode nove propise. Uredbe su svuda drugačije u svetu; postoji stotine zakona i pravnih akata koji proističu od nacionalnih i lokalnih vlasti, i koji pokrivaju različite aspekte privrede. U radu se razmatraju međunarodni sporazumi kapitala i zakonskih akata koji su odgovorni za stabilnost finansijskog sektora i njegovih članova, što dovodi do ukupne stabilnosti društva. Analiza savremene literature otkriva zemlje koje su uspele da sprovedu veoma zahtevne kriterijume.
Ključne reči:

regulativa,

Bazel standardi, stabilnost. 